\title{
PENGARUH KUALITAS KEHIDUPAN KERJA DAN KEPUASAN KERJA TERHADAP KETERLEKATAN PEGAWAI GENERASI X DAN GENERASI Y PADA PT. YUDHISTIRA GHALIA INDONESIA
}

\author{
THE EFFECT OF QUALITY OF WORK-LIFE AND JOB SATISFACTION ON GENERATION X AND \\ GENERATION Y' EMPLOYEE ENGAGEMENT AT PT. YUDISHTIRA GHALIA INDONESIA
}

\author{
Nurheni $^{* 1}$, Anggraini Sukmawati*), dan Sukiswo Dirdjosuparto ${ }^{*}$ \\ *) Departemen Manajemen, Fakultas Ekonomi dan Manajemen, IPB University \\ Jl. Kamper Kampus IPB Darmaga, Bogor 16680
}

\begin{abstract}
Employee engagement is one of the keys to the success of a company to achieve its vision and mission optimally. This research was conducted to analyze the effect of quality of work-life and job satisfaction on employee engagement in each generation at PT. Yudhistira Ghalia Indonesia. The analytical tools were Structural Equation Modeling - Partial Least Square and Multi-group Analysis. The results show that the quality of work-life had a significant positive effect on job satisfaction and employee engagement of Generation X and Generation Y; job satisfaction had a significant positive effect on employee engagement of Generation $X$ and Generation $Y$; generation did not act as a moderator (moderating variable), it means the strong-weak influenced between latent variables did not depend on generation. The analysis implied that the improvement of the quality of work-life and job satisfaction would increase employee engagement of Generation X and Generation Y at PT. Yudhistira Ghalia Indonesia.
\end{abstract}

Keywords: employee engagement, generation $X$, generation $Y$, job satisfaction, quality of work life

\begin{abstract}
Abstrak: Keterlekatan pegawai adalah salah satu kunci keberhasilan perusahaan untuk mencapai visi dan misi secara optimal. Tujuan penelitian ini adalah menganalisis pengaruh kualitas kehidupan kerja (quality of work life) dan kepuasan kerja (job satisfaction) terhadap keterlekatan pegawai (employee engagement) pada setiap kelompok generasi di PT. Yudhistira Ghalia Indonesia. Penelitian ini menggunakan metodelogi analisis, yaitu Structural Equation Modeling - Partial Least Square dan Multigroup Analysis. Hasil penelitian ini menunjukkan bahwa kualitas kehidupan kerja berpengaruh positif signifikan terhadap kepuasan kerja dan keterlekatan pegawai (employee engagement) pada Generasi X dan Generasi Y; kepuasan kerja berpengaruh positif dan signifikan terhadap keterlekatan pegawai pada Generasi X dan Generasi Y; generasi tidak berperan sebagai moderator (variabel moderasi) yang bermakna kuat-lemahnya pengaruh antara variabel laten tidak tergantung pada generasi. Implikasi dari penelitian ini adalah dengan PT. Yudhistira Ghalia Indonesia meningkatkan kualitas kehidupan kerja dan kepuasan kerja, pegawai Generasi X dan Generasi Y dengan keterlekatan pegawai yang tinggi pun akan meningkat.
\end{abstract}

Kata kunci: generasi X, generasi Y, kepuasan kerja, keterlekatan pegawai, kualitas kehidupan kerja

\footnotetext{
${ }^{1}$ Corresponding author:

Email:mwiwi88@gmail.com
} 


\section{PENDAHULUAN}

Employee engagement atau keterlekatan pegawai dalam beberapa tahun terakhir ini telah menjadi sebuah agenda penting bagi para pemimpin bisnis. Survey yang dilakukan oleh Hay Group Holdings (2009) menyatakan bahwa pegawai dengan tingkat keterlekatan pegawai yang tinggi dapat meningkatkan kinerja bisnis hingga 30\% (MetLife Mature Market Institute \& Generations United, 2009). Hal tersebut didukung oleh hasil penelitian Gallup pada tahun 2012 yang menyatakan bahwa unit kerja dengan pegawai yang memiliki keterlekatan pegawai tinggi (engaged) menghasilkan lebih tinggi $21 \%$ productivity dan lebih besar $22 \%$ profitability dibandingkan productivity dan profitability yang dihasilkan unit kerja dengan pegawai yang memiliki employee engagement rendah (disengaged) (Sorenson, 2013).

Keterlekatan pegawai adalah salah satu kunci keberhasilan untuk mencapai visi dan misi perusahaan secara optimal, karena pegawai yang memiliki keterlekatan pegawai yang tinggi (engaged) adalah pegawai yang secara konsisten berbicara positif tentang organisasinya baik dalam pergaulan internal maupun pihak luar, seperti: pelanggan atau calon pegawai; memiliki keinginan yang kuat untuk tetap tinggal di organisasi, terlepas dari kesempatan yang ada di luar; dan mereka memiliki motivasi dan berusaha dengan memberikan tenaga, waktu, dan kompentensi yang mereka miliki terhadap pekerjaannya untuk mencapai kesuksesan organisasi (Hewitt, 2015).

Pada tahun 2015 Prasetiya Mulya Executive Learning Institute melakukan riset terhadap pegawai dari berbagai perusahaan terkemuka di Indonesia yang menyatakan bahwa terdapat perbedaan tingkat employee engagement berdasarkan ragam generasi, dimana pegawai generasi $\mathrm{X}$ memiliki tingkat engaged sebesar $47 \%$ dan notengaged sebesar 53\%; serta pegawai generasi $\mathrm{Y}$ memiliki tingkat engaged sebesar $28 \%$, not-engaged sebesar $71 \%$, dan actively disengaged sebesar $1 \%$ (Laterna, 2015). Kupperschmidt (2000) menyatakan bahwa generasi adalah sekelompok individu yang mengidentifikasi kelompoknya berdasarkan jangka waktu tahun kelahiran, rentang umur dan lokasi/wilayah yang sama, serta mengalami peristiwa kehidupan (life events) yang sama yang berpengaruh signifikan terhadap tahapan penting dalam pertumbuhan hidup mereka. Peristiwa kehidupan (life events) setiap generasi memiliki karakteristik unik yang terbentuk dari kondisi ekonomi, politik, dan perkembangan teknologi yang terjadi pada periode tersebut.

Perusahaan harus menyadari bahwa terdapat perbedaan pola perilaku lintas generasi dan bagaimana tuntutan lingkungan kerja harus menyesuaikan perkembangan zaman berdasarkan perubahan generasi tersebut. Meski demikian, perbedaan generasi tak dapat sepenuhnya dinilai sebagai perbedaan mutlak, mengingat sekelompok generasi adalah juga produk dari generasi sebelumnya. Yang menjadi tantangan bagi para pemimpin adalah bagaimana seni untuk senantiasa meningkatkan engagement pegawainya dari segenap generasi, dengan mengenali karakteristik dan perbedaan mereka, mengingat bahwa setiap generasi adalah memberi kontribusi dan tiap generasi akan meneruskan tongkat estafet kepemimpinan bagi generasi selanjutnya.

Membangun keterlekatan pegawai adalah sebuah proses dua arah yang melibatkan perusahaan berinisitatif (aksi) dan pegawai merespon (reaksi). Asumsi dasar yang digunakan adalah ketika pegawai menerima sesuatu dari perusahaan, maka mereka akan merasa memiliki kewajiban untuk membayarnya dengan tingkat keterlekatan yang tinggi (Saks, 2006). Aksi yang dapat dilakukan oleh perusahaan untuk memperoleh reaksi berupa keterlekatan pegawai yang tinggi adalah kualitas kehidupan kerja (quality of work life) dan kepuasan kerja pegawai (job satisfaction). Hal tersebut didukung oleh hasil penelitian Rusdin (2015) menyatakan bahwa quality of work life berpengaruh positive significant terhadap keterlekatan pegawai dan hasil penelitian Kwasira \& Waigwa (2014) yang menyatakan bahwa kepuasan kerja memiliki hubungan positif dengan employee engagement. Sehingga, dapat disimpulkan bahwa dengan pemenuhan faktor-faktor quality of work life dan job satisfaction secara optimal dapat menghasilkan tingkat keterlekatan pegawai yang tinggi.

Flippo (1997) mendefinisikan quality of work life (QWL) sebagai kegiatan pada setiap tingkatan dalam suatu organisasi yang bertujuan meningkatkan efektivitas organisasi melalui peningkatan martabat dan pertumbuhan pegawai yang berhubungan dengan kepuasan yang tinggi atas pekerjaannya (Fatehi et al. 2015). Spector (1997) menyatakan bahwa kepuasan kerja (job satisfaction) pegawai menunjukkan tingkat 
puas, senang, dan bahagia seorang pegawai terhadap pekerjaannya, serta dapat diartikan sebagai keadaan dimana terpenuhinya keinginan dan kebutuhan pegawai di tempat kerja, sehingga kepuasan kerja dapat dikatakan sebagai kriteria sejauhmana seorang pegawai menyukai pekerjaan mereka (Khan et al. 2015).

PT. Yudhistira Ghalia Indonesia merupakan salah satu pelaku usaha penerbitan yang melayani kebutuhan bahan ajar bagi siswa dan pendidik di tingkat $\mathrm{SD}$ / MI, SMP/MTs, SMA/MA, SMK, serta buku-buku teks perguruan tinggi dan umum. Visi PT. Yudhistira Ghalia Indonesia adalah mendharmabaktikan diri pada dunia perbukuan, untuk berperanserta mencerdaskan kehidupan bangsa guna meningkatkan kualitas sumber daya manusia Indonesia. Dengan misi PT. Yudhistira Ghalia Indonesia yang berupaya dalam menciptakan buku bermutu untuk memenuhi sarana pendidikan bangsa, memenuhi kebutuhan pelanggan dengan memberikan pelayanan terbaik melalui jaringan distribusi yang kuat dan luas, serta menumbuhkan perusahaan yang sehat secara berkesinambungan dari tahun ke tahun.

Berdasarkan teori dan fakta yang telah dibahas sebelumnya, untuk dapat mewujudkan visi dan misi perusahaan secara optimal, PT. Yudhistira Ghalia Indonesia membutuhkan pegawai dengan tingkat keterlekatan yang tinggi pada setiap generasi, karena mereka akan menggunakan segala sumber daya yang dimiliki: waktu, pemikiran dan energi untuk pekerjaan, serta proaktif dan persisten untuk memajukan perusahaan. Pegawai dengan tingkat keterlekatan yang tinggi dapat dimiliki oleh perusahaan melalui pemenuhan kualitas kehidupan kerja (quality of work life) dan kepuasan kerja pegawai (job satisfaction) secara optimal.

Tujuan yang ingin dicapai dalam penelitian ini adalah Menganalisis tingkat keterlekatan pegawai (employee engagement) pada Generasi X dan Generasi Y di PT. Yudhistira Ghalia Indonesia. Selanjutnya, menganalisis pengaruh kualitas kehidupan kerja (quality of work life) dan kepuasan kerja (job satisfaction) terhadap keterlekatan pegawai (employee engagement) pada Generasi X dan Generasi Y di PT. Yudhistira Ghalia Indonesia. Di samping itu, untuk menganalisis peran generasi sebagai moderator (variabel moderasi) di antara variabel laten dalam model penelitian ini.

\section{METODE PENELITIAN}

Populasi dalam penelitian ini adalah 248 pegawai PT. Yudhistira Ghalia Indonesia yang berada di Jl. Rancamaya Km. 1 No. 47, Warung Nangka, Ciawi, Bogor, 16720 dengan teknik pengambilan sampel yang digunakan dalam penelitian ini adalah simple random sampling. Dalam penelitian ini, sampel dibagi dalam kategori generasi maka diperlukan ukuran sampel minimal 30 responden untuk setiap kategori (Agung, 2006), hal tersebut sesuai dengan pernyataan Gall et al. (2007) yang menyatakan bahwa penelitian eksperimen dan komparatif membutuhkan sampel 1530 responden untuk setiap kelompok dan sesuai dengan alat analisis yang digunakan, yaitu structural equation modeling-partial least square dengan jumlah sampel yang representatif 30-100 sampel. Jumlah sampel pada setiap kelompok yang dianalisis dalam penelitian ini, yaitu Generasi X dan Generasi Y tertera pada Tabel 1.

Tabel 1. Jumlah responden berdasarkan generasi

\begin{tabular}{lcc}
\hline Kelompok & Jumlah & $\%$ \\
\hline Generasi Baby Boomer (1946-1964) & 5 & 4,90 \\
Generasi X (1965-1979) & 56 & 54,90 \\
Generasi Y (1980-1996) & 40 & 39,22 \\
Gen Z (1997-saat ini) & 1 & 0,98 \\
\hline Total & 102 & 100,00 \\
\hline
\end{tabular}

Pengumpulan data dalam penelitian ini dilakukan dengan wawancara terstruktur dengan menggunakan kuesioner yang bersifat tertutup dengan menggunakan skala Likert. Selanjutnya, data yang telah dikumpulkan, dilakukan analisis descriptive, analisis SEM dengan pendekatan PLS (Partial Least Squares) dengan bantuan Software SmartPLS 3.0, dan mulitigroup analysis. Adapun untuk keperluan penolakan atau penerimaan hipotesis, penelitian ini menggunakan taraf signifikansi $5 \%(\alpha=0,05)$. Analisis multigroup atau sering disebut analisis multisample bertujuan membandingkan analisis data berdasarkan karakteristik sampel dengan dua atau lebih data set (Ghozali dan Latan, 2015).

Hasil penelitian Rusdin (2015) menyatakan bahwa quality of work life berpengaruh positive significant terhadap keterlekatan pegawai. Selanjutnya, Deshwal (2015) yang menyatakan bahwa job satisfaction memiliki hubungan positif yang signifikan terhadap employee engagement. Berdasarkan teori tersebut dibuatlah kerangka pemikiran penelitian pada Gambar 1 dan dihasilkan hipotesis sebagai berikut: 
H1: Kualitas kehidupan kerja (quality of work life) berpengaruh positif secara signifikan terhadap kepuasan kerja (job satisfaction) pada PT. Yudhistira Ghalia Indonesia.

$\mathrm{H} 2$ : Kualitas kehidupan kerja (quality of work life) berpengaruh positif secara signifikan terhadap keterlekatan pegawai (employeee engagement) pada PT. Yudhistira Ghalia Indonesia.

H3: Kepuasan kerja (job satisfaction) berpengaruh positif secara signifikan terhadap keterlekatan pegawai (employeee engagement) pada PT. Yudhistira Ghalia Indonesia.

\section{HASIL}

Hasil analisis deskriptif (Gambar 2) yang menunjukkan persentase jumlah pegawai yang memiliki keterlekatan pegawai yang tinggi (engaged) adalah pegawai yang secara konsisten berbicara positif tentang organisasinya baik dalam pergaulan internal maupun pihak luar, seperti: pelanggan atau calon pegawai; memiliki keinginan yang kuat untuk tetap tinggal di organisasi, terlepas dari kesempatan yang ada di luar; dan mereka berjuang (are motivated and exert effort) dengan memberikan tenaga, waktu, dan kompentensi mereka terhadap pekerjaannya untuk mencapai kesuksesan organisasi (Hewitt, 2015). Pegawai not engaged adalah pegawai yang hadir dan ambil bagian dari pekerjaan, namun sekedar memenuhi tuntutan kerja, tanpa semangat dan gairah dalam melakukan pekerjaannya; pegawai actively disengaged adalah pegawai yang merasa tidak senang atas kondisi kerjanya dan mengekspresikan ketidak-senangannya tersebut, sehingga mengganggu produktivitas pegawai lain dan mereka tidak menghargai (undermine) prestasi yang dihasilkan oleh para pegawai engaged (Lockwood, 2007).

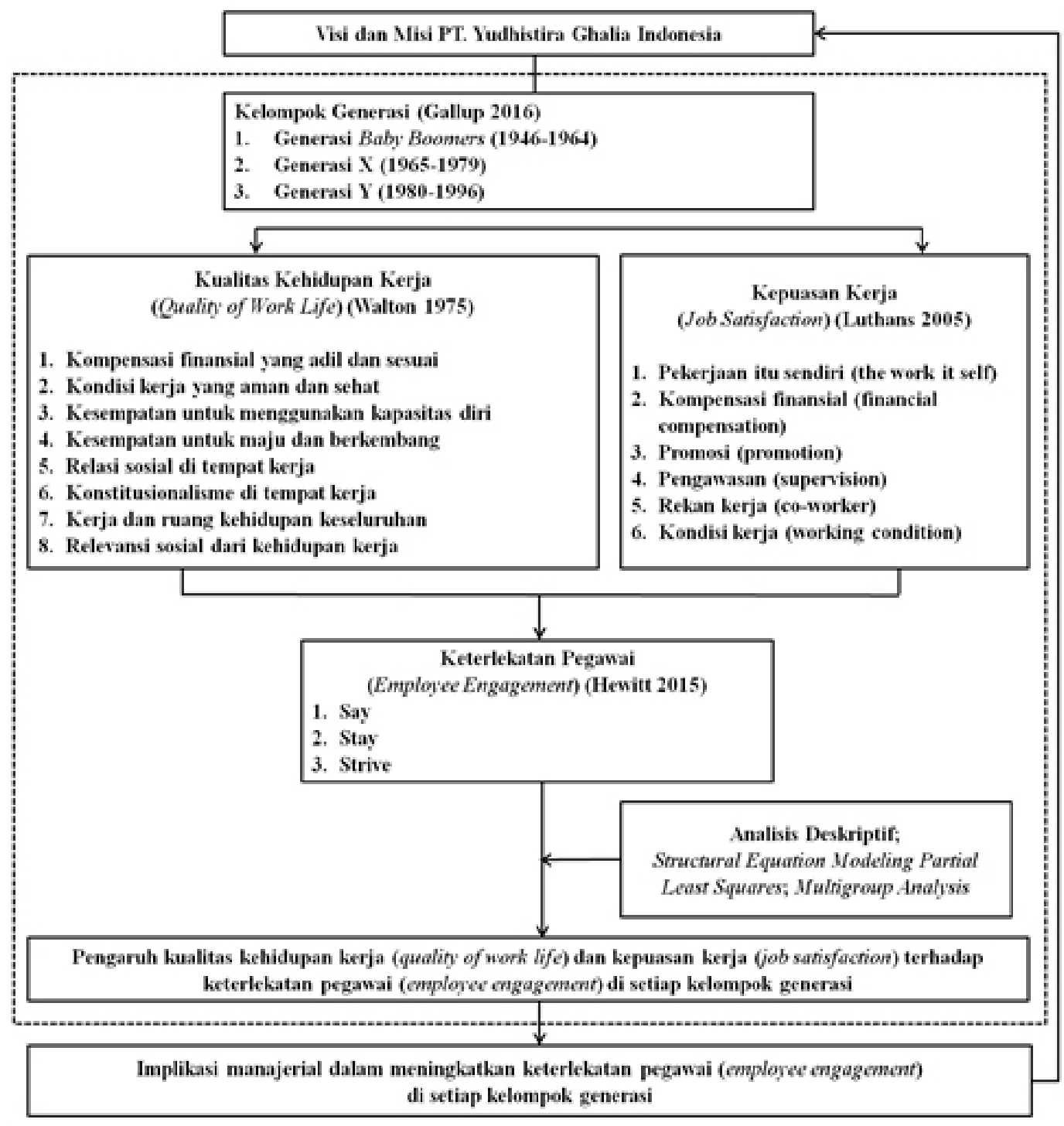

Gambar 1. Kerangka pemikiran penelitian 


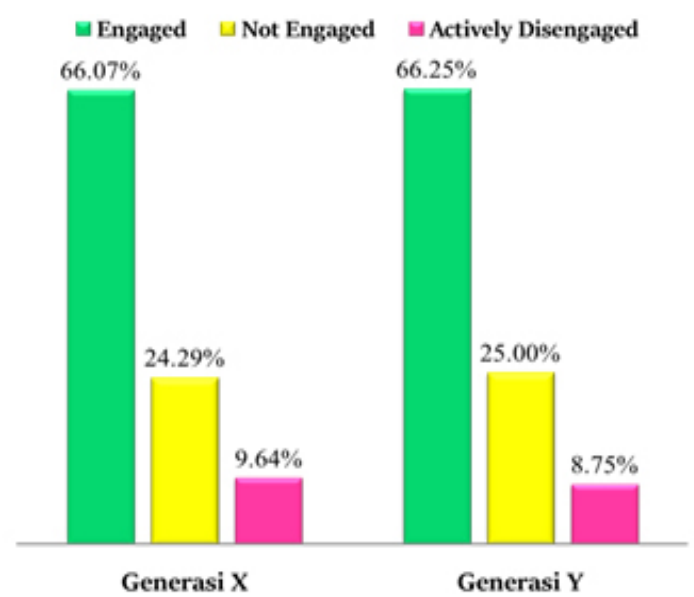

Gambar 2. Tingkat keterlekatan pegawai (employee engagement)

\section{Pengaruh Kualitas Kehidupan Kerja (Quality of Work Life) dan Kepuasan Kerja (Job satisfaction) terhadap Keterlekatan Pegawai (Employee engagement)}

Hasil analisis PLS Algorithm dan bootstrapping (Gambar 3-6) dengan selang kepercayaan 95\% yang menghasilkan nilai t-Statistics seluruh jalur dalam model struktural penelitian sehingga diperoleh hipotesis dengan membandingkan t-Statistics total effects terhadap t-tabel $=1.96$ (signifikansi alpha 5\%) yang tertera pada Tabel 2.

Hipotesis penelitian ( $\mathrm{H} 1$ dan $\mathrm{H} 2$ ) pada Tabel 2 menjelaskan bahwa peningkatan terhadap quality of work life akan meningkatkan job satisfaction dan employee engagement pegawai Generasi $\mathrm{X}$ dan pegawai Generasi Y. Hasil penelitian ini sejalan dengan hasil penelitian yang dilakukan oleh Tabassum (2012) yang menyatakan bahwa quality of work life memiliki hubungan positifyang signifikan dengan job satisfaction pegawai fakultas di Private University of Bangladesh; serta hasil penelitian yang dilakukan oleh Rizaliani (2016) yang menyatakan bahwa quality of work life memiliki pengaruh yang signifikan terhadap employee engagement pegawai PT Pasifik Satelit Nusantara.

Tabel 3 merupakan hasil dari multigroup analysis yang menyatakan bahwa perbedaan pengaruh quality of work life terhadap job satisfaction antara Generasi $\mathrm{X}$ dengan Generasi $\mathrm{Y}$ adalah tidak signifikan (not significant), sehingga dapat dinyatakan bahwa generasi tidak berperan sebagai moderator (variabel moderasi) yang bermakna kuat-lemahnya pengaruh quality of work life terhadap job satisfaction tidak tergantung pada generasi. Belum tersedianya penelitian terdahulu yang melakukan multigroup analysis pengaruh quality of work life terhadap job satisfaction dengan generasi sebagai moderator.

Selanjutnya, perbedaan pengaruh quality of work life terhadap employee engagement antara Generasi $\mathrm{X}$ dengan Generasi $\mathrm{Y}$ adalah tidak signifikan (not significant), sehingga dapat dinyatakan bahwa generasi tidak berperan sebagai moderator (variabel moderasi) yang bermakna kuat-lemahnya pengaruh quality of work life terhadap employee engagement tidak tergantung pada generasi. Belum tersedianya penelitian terdahulu yang melakukan multigroup analysis pengaruh quality of work life terhadap employee engagement dengan generasi sebagai moderator.

Hipotesis (H3) penelitian pada Tabel 2 menjelaskan bahwa peningkatan terhadap job satisfaction akan meningkatkan employee engagement pegawai Generasi $\mathrm{X}$ dan pegawai Generasi Y. Hasil penelitian ini sejalan dengan hasil penelitian yang dilakukan oleh Janah et al. (2017) yang menyatakan bahwa job satisfaction berpengaruh positif secara signifikan terhadap employee engagement karyawan UKM klaster makanan dan minuman di kota Bogor; serta hasil penelitian yang dilakukan oleh Deshwal (2015) yang menyatakan bahwa job satisfaction memiliki hubungan positif yang signifikan terhadap employee engagement pegawai yang berkerja di hospitality sector from Gurgaon and Ghaziabad region.

Tabel 4 merupakan hasil dari multigroup analysis yang menyatakan bahwa perbedaan pengaruh kepuasan kerja (job satisfaction) terhadap keterlekatan pegawai (employee engagement) antara Generasi X dengan Generasi $\mathrm{Y}$ adalah tidak signifikan (not significant), sehingga dapat dinyatakan bahwa generasi tidak berperan sebagai moderator (variabel moderasi) yang bermakna kuat-lemahnya pengaruh job satisfaction terhadap employee engagement tidak tergantung pada generasi. Belum tersedianya penelitian terdahulu yang melakukan multigroup analysis pengaruh kepuasan kerja (job satisfaction) terhadap keterlekatan pegawai (employee engagement) dengan generasi sebagai moderator. Namun, terdapat penelitian oleh Park \& Gursoy (2012) yang menunjukkan bahwa perbedaan pengaruh work engagement (keterlekatan kerja) terhadap job satisfaction antara Generasi X dengan 
Generasi Y adalah signifikan, sehingga generasi berperan sebagai moderator (variabel moderasi) secara signifikan, yang bermakna kuat-lemahnya pengaruh work engagement terhadap job satisfaction tergantung pada generasi.

Analisis PLS Algorithm dan bootstrapping dengan selang kepercayaan 95\% menunjukkan bahwa peningkatan terhadap quality of work life dan job satisfaction akan meningkatkan employee engagement pegawai Generasi X dan pegawai Generasi Y dengan indikator quality of work life dan job satisfaction yang memiliki pengaruh positif secara signifikan terhadap employee engagement pegawai Generasi $\mathrm{X}$ dan pegawai Generasi Y seperti yang tertera pada Gambar 3-6, dijelaskan pada Tabel 5.

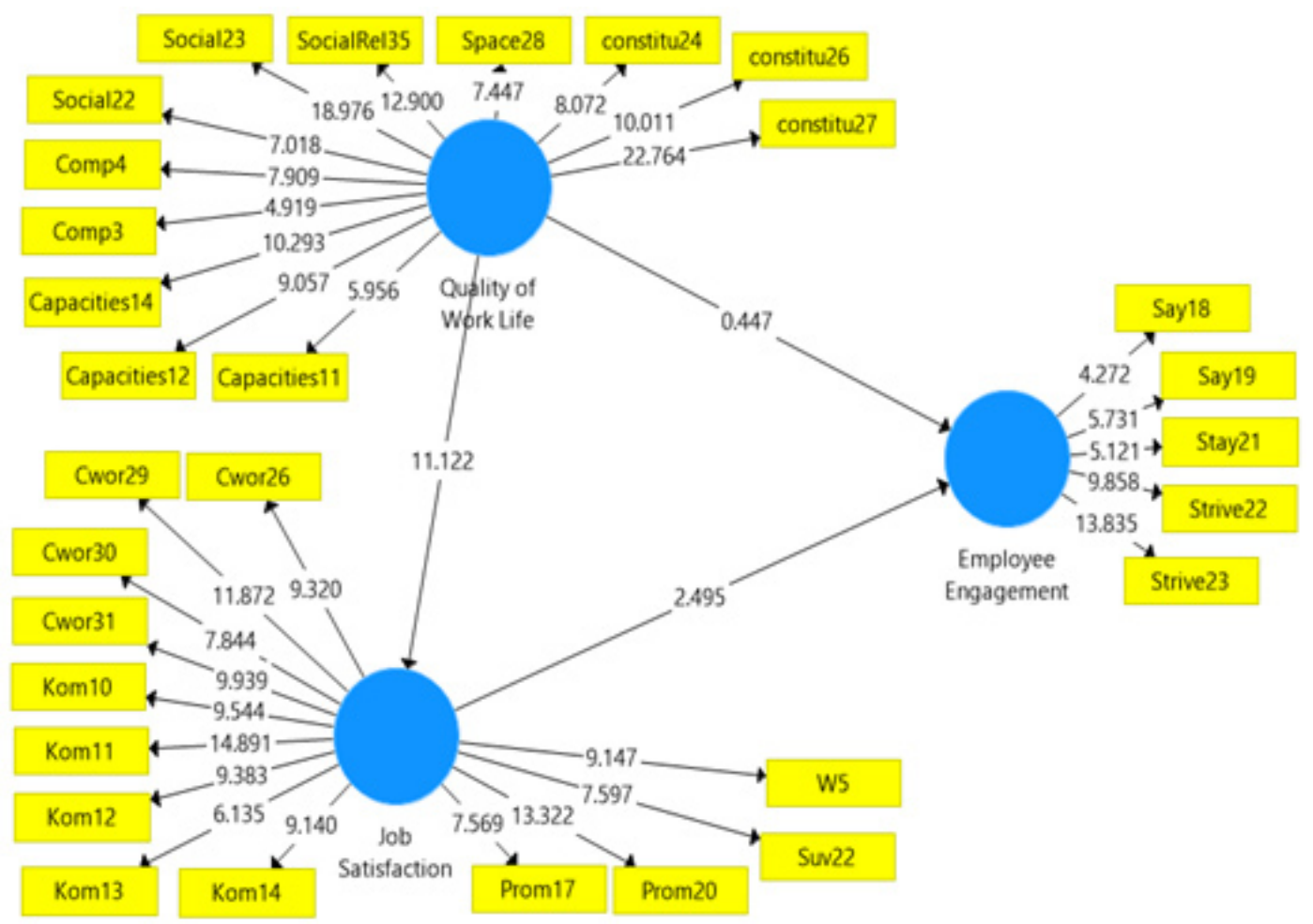

Gambar 3. Output bootstrapping path coefficient Generasi X

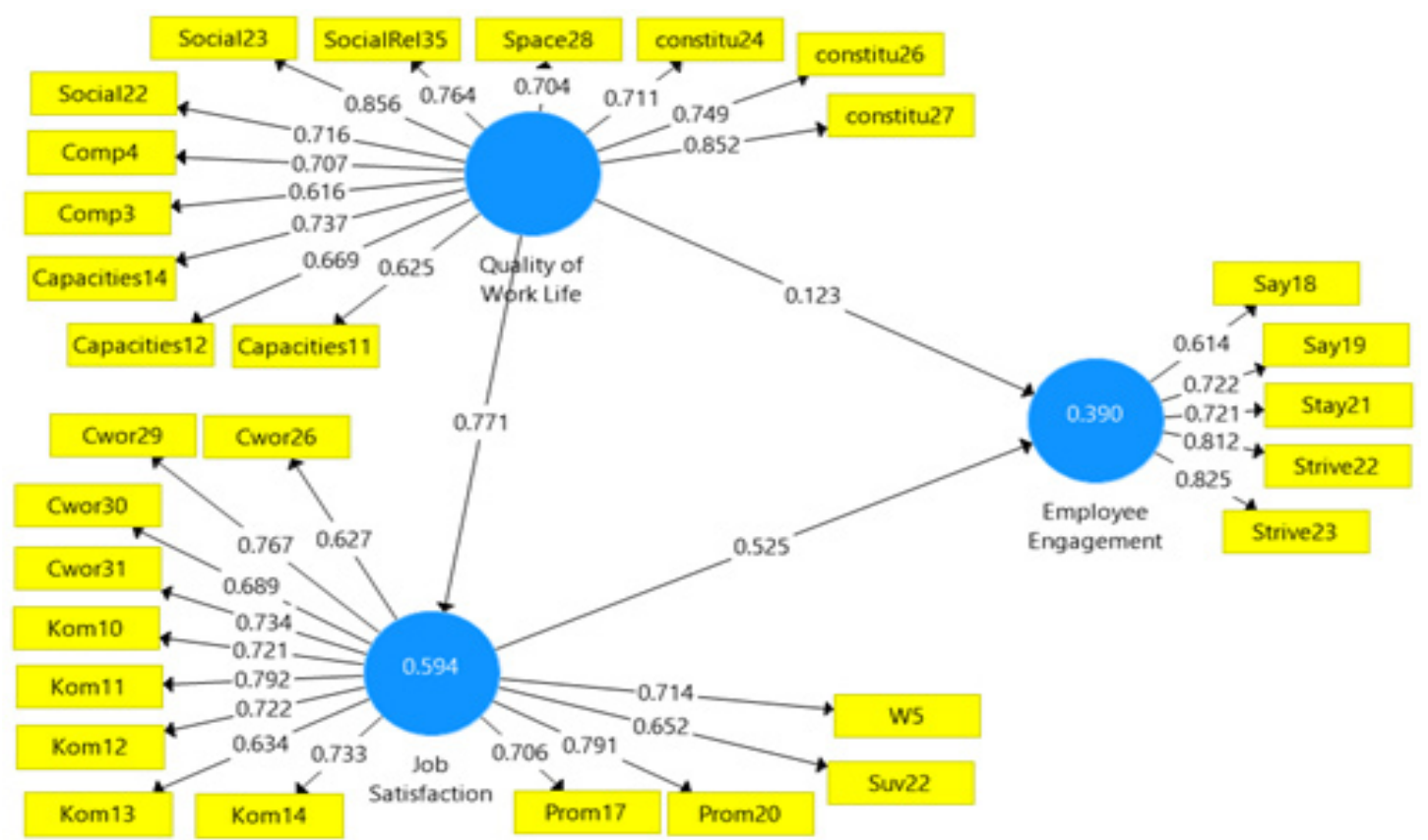

Gambar 4. Output PLS algorithm path coefficient Generasi X 


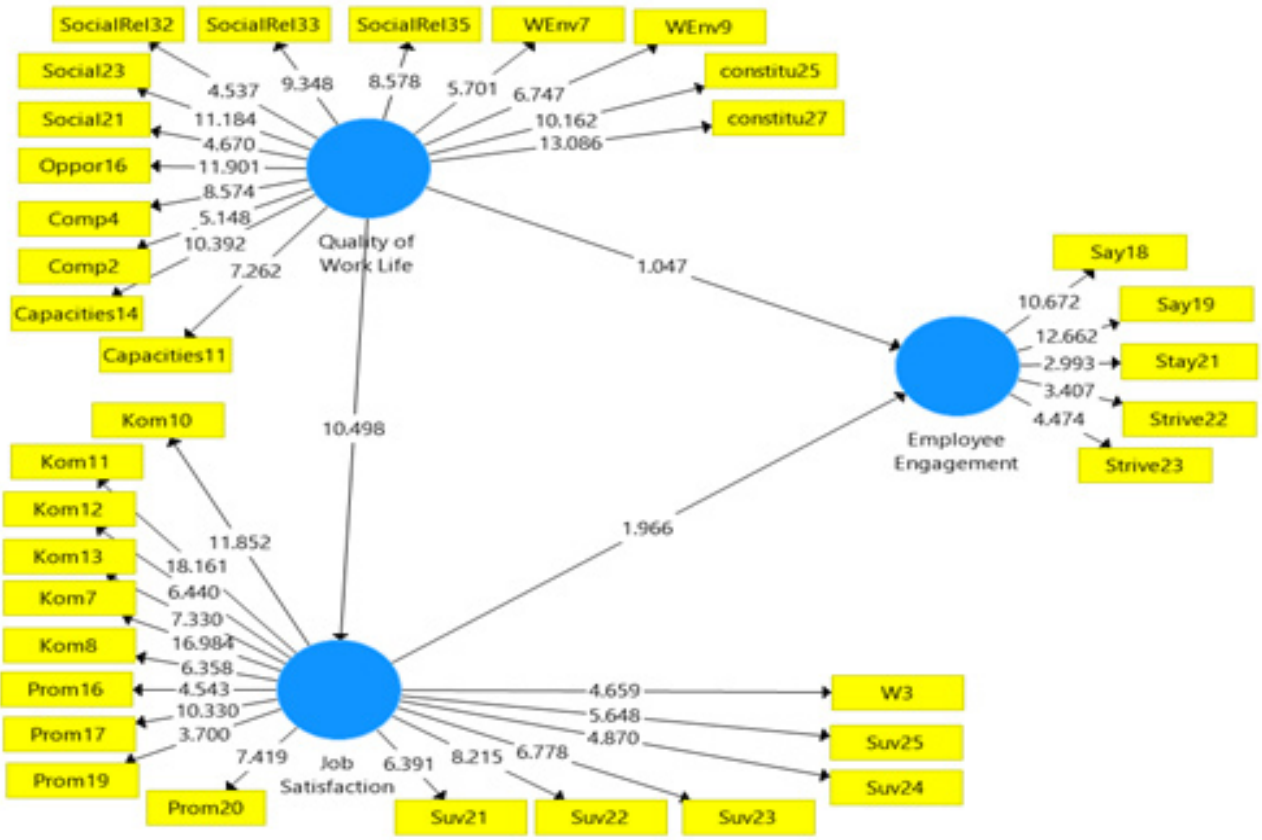

Gambar 5. Output bootstrapping path coefficient Generasi Y

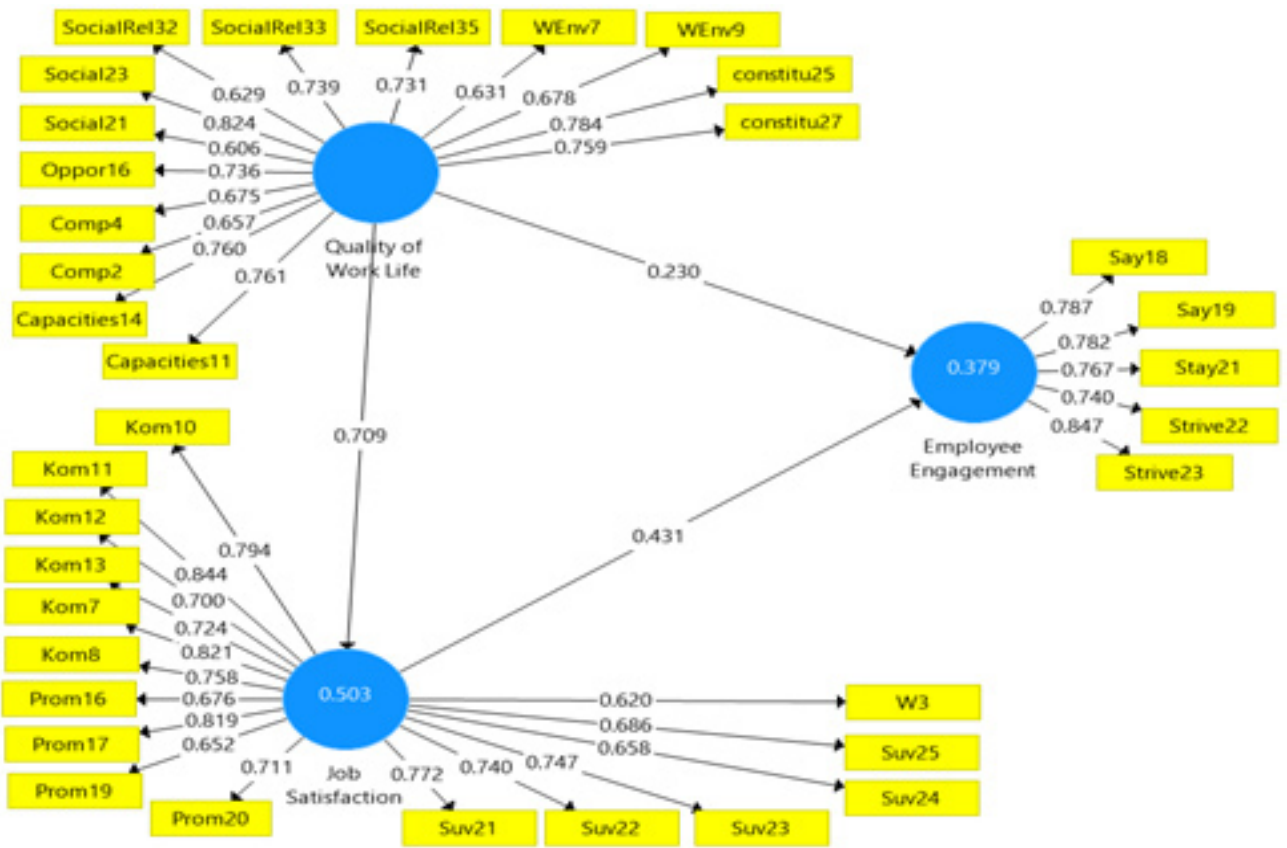

Gambar 6. Output PLS algorithm path coefficient Generasi Y

Tabel 2. Hipotesis Penelitian

\begin{tabular}{|c|c|c|}
\hline Hipotesis & Generasi X & Generasi Y \\
\hline $\begin{array}{l}\text { H1: Kualitas kehidupan kerja (quality of work life) berpengaruh positif secara signifikan } \\
\text { terhadap kepuasan kerja (job satisfaction) pada PT. Yudhistira Ghalia Indonesia. }\end{array}$ & $\begin{array}{l}\text { t-stat }=11,122 \\
\text { H1diterima }\end{array}$ & $\begin{array}{l}\text { t-stat }=10,498 \\
\text { H1 diterima }\end{array}$ \\
\hline $\begin{array}{l}\text { H2: Kualitas kehidupan kerja (quality of work life) berpengaruh positif secara signifikan } \\
\text { terhadap keterlekatan pegawai (employee engagement) pada PT. Yudhistira Ghalia } \\
\text { Indonesia. }\end{array}$ & $\begin{array}{l}\mathrm{t}-\mathrm{stat}=, 241 \\
\mathrm{H} 2 \text { diterima }\end{array}$ & $\begin{array}{l}\text { t-stat }=4,564 \\
\mathrm{H} 2 \text { diterima }\end{array}$ \\
\hline $\begin{array}{l}\text { H3: Kepuasan kerja (job satisfaction) berpengaruh positif secara signifikan terhadap } \\
\text { keterlekatan pegawai (employee engagement) pada PT. Yudhistira Ghalia Indonesia }\end{array}$ & $\begin{array}{l}\mathrm{t} \text {-stat }=2,495 \\
\mathrm{H} 3 \text { diterima }\end{array}$ & $\begin{array}{l}\text { t-stat }=1,966 \\
\text { H3 diterima }\end{array}$ \\
\hline
\end{tabular}


Tabel 3. Analisis multigroup pengaruh quality of work life terhadap job satisfaction dan employee engagement

\begin{tabular}{lcccc}
\hline Quality of Work Life $\rightarrow$ Job Satisfaction & \multicolumn{3}{c}{ T-statistic } & P-Value \\
\hline & Gen X & Gen Y & 0,627 & 0,532 \\
\hline Original Estimasi (Path) & 0,771 & 0,709 & \multicolumn{2}{c}{ not significant } \\
Standard Error (S.E.) & 0,069 & 0,068 & \multicolumn{2}{c}{ T-statistic } \\
\hline Quality of Work Life $\rightarrow$ Employee Engagement & Gen X & Gen Y & 0,042 & 0,967 \\
\hline \multicolumn{2}{c}{ Original Estimasi (Path) } & 0,527 & 0,536 & \multicolumn{2}{c}{ not significant } \\
Standard Error (S.E.) & 0,163 & 0,117 & \multicolumn{2}{c}{} \\
\hline
\end{tabular}

Tabel 4. Analisis multigroup pengaruh job satisfaction terhadap employee engagement

\begin{tabular}{lcccc}
\hline Job Satisfaction $\rightarrow$ Employee Engagement & & & \\
\hline & Gen X & Gen Y & T-statistic & P-Value \\
\hline Original Estimasi (Path) & 0,525 & 0,431 & 0,306 & 0,760 \\
Standard Error (S.E.) & 0,210 & 0,219 & \multicolumn{2}{c}{ not significant } \\
\hline
\end{tabular}

Tabel 5. Indikator quality of work life dan job satisfaction berpengaruh positif yang signifikan terhadap employee engagement

\begin{tabular}{lcc}
\hline Indicator of Quality of Work Life & Generasi X & Generasi Y \\
\hline Adequate and fair financial compensation & $\sqrt{ }$ \\
Safe and healthy environment & - & $\sqrt{ }$ \\
The use of your capacities at the work & $\sqrt{ }$ & $\sqrt{ }$ \\
Opportunities that you have at your work & $\sqrt{ }$ & $\sqrt{ }$ \\
The social integration in the work organization & $\sqrt{ }$ \\
The constitutionalism in the work organization & $\sqrt{ }$ & - \\
Work and total life space & $\sqrt{ }$ & $\sqrt{ }$ \\
The social relevance and importance of your work & Generasi X & Generasi Y \\
\hline Indicator of Job Satisfaction & $\sqrt{ }$ & $\sqrt{ }$ \\
\hline The work its self & $\sqrt{ }$ & $\sqrt{ }$ \\
Financial compensation & $\sqrt{ }$ \\
Promotion & $\sqrt{ }$ & $\sqrt{ }$ \\
Supervision & $\sqrt{ }$ & - \\
Co-worker & - & - \\
\hline Working condition & & \\
\hline
\end{tabular}

\section{Implikasi Manajerial}

PT. Yudhistira Ghalia Indonesia untuk memperoleh peningkatan keterlekatan pegawai (employee engagement) pada Generasi X adalah Peningkatan terhadap relasi (relationship) antara pegawai dengan atasan dan pegawai dengan rekan kerja, melalui: atasan melakukan peningkatan dalam memberikan bimbingan (teknis dan moral) mengenai pelaksanaan pekerjaan dan peningkatan terhadap kerja kelompok (kerja tim), sehingga tercipta hubungan saling menghormati, saling mendukung, dan bekerja sama antara rekan kerja yang semakin kuat, yang akan membawa peningkatan kinerja pegawai dalam upaya mewujudkan visi dan misi perusahaan secara optimal; Perusahaan mengatasi perselisihan (konflik) berdasarkan peraturan dan hukum yang berlaku; serta perusahaan memberi kebebasan kepada pegawai untuk menjadi anggota serikat pekerja, serikat pekerja merupakan simbol kekuatan pekerja dalam menuntut kebutuhannya terhadap perusahaan, karena peran serikat pekerja adalah memperjuangkan kepentingan para pekerja; Pengaturan waktu/jadwal kerja yang dapat menciptakan keseimbangan antara kehidupan kekaryaan (pekerjaan) dan kehidupan/ 
rutinitas dengan keluarga pegawai. Perusahaan menawarkan waktu cuti kerja kepada pegawai, waktu libur yang dapat digunakan oleh pegawai untuk berkumpul bersama keluarga. Dan perusahaan menciptakan program-program yang dapat mempererat hubungan antar pegawai dengan keluarganya, seperti: family gathering dimana setiap pegawai dibolehkan untuk membawa anggota keluarga mereka.

PT. Yudhistira Ghalia Indonesia untuk memperoleh peningkatan keterlekatan pegawai (employee engagement) pada Generasi Y adalah Peningkatan relasi (relationship) antara pegawai dengan atasan, melalui: pemberian informasi mengenai target kerja (tujuan kerja yang ingin dicapai) dengan rinci dan jelas kepada pegawai, memberikan bimbingan (teknis dan moral) mengenai pelaksanaan pekerjaan, dan membantu mencari solusi untuk mengatasi permasalahan yang pegawai hadapi ketika menyelesaikan pekerjaan; Peningkatan terhadap kesempatan untuk mengungkapkan pendapat (kebebasan untuk berekspresi); Peningkatan atas penggunaan teknologi dengan pelatihan dalam penggunaan teknologi tersebut yang akan mendorong kreativitas dan inovasi pegawai, selain itu penggunaan teknologi dapat mewujudkan lingkungan kerja yang aman dari kecelakaan kerja dan kejahatan kriminal.

PT. Yudhistira Ghalia Indonesia untuk memperoleh peningkatan keterlekatan pegawai (employee engagement) pada Generasi $\mathrm{X}$ dan Generasi $\mathrm{Y}$ adalah peningkatan dalam penggunaan kemampuan, keterampilan, dan pengetahuan yang pegawai miliki, melalui: peningkatan penerimaan perusahaan terhadap ide-ide dan inisiatif yang pegawai sampaikan (ajukan) dan peningkatan kesempatan dalam menggunakan otonomi (mengambil keputusan yang bertanggung jawab) dalam menyelesaikan pekerjaan yang menjadi tanggung jawab pegawai. Selanjutnya, perusahaan dapat menantang pegawai melalui job enlargement (pemekaran pekerjaan), yaitu memperluas pekerjaan secara horizontal dengan menambah jumlah dan keragaman tugas untuk dikerjakan oleh seorang pegawai sebagai sarana mengasah competency yang pegawai miliki. Peningkatan terhadap kesempatan yang sama untuk memperoleh promosi pekerjaan yang disertai dengan kenaikan gaji berdasarkan prestasi kerja yang dibarengi dengan peningkatan atas kesempatan yang sama untuk melanjutkan pendidikan sebagai upaya untuk mengembangkan kemampuan guna mendukung peningkatan peran pekerjaan yang menjadi tanggung jawab (work responsibility) pegawai terhadap kesuksesan perusahaan sehingga pegawai berkembang dan menjadi lebih profesional (maju dalam karier). Peningkatan terhadap gaji, tunjangan, dan insentif pegawai berdasarkan prestasi kerja dan peningkatan terhadap tunjangan dan gaji yang pegawai terima dibandingkan dengan gaji di perusahaan lain yang sejenis. Peningkatan terhadap penghormatan personal privacy (urusan pribadi) pegawai, dimana perusahaan menghargai keleluasan pribadi dan tidak ada pihak yang campur tangan dalam urusan pribadi seorang pegawai; Menyelaraskan langkah para pegawainya untuk bergerak bersama secara sinergi dalam mencapai peningkatan citra perusahaan di masyarakat melalui kontribusi perusahaan kepada masyarakat berupa pelayanan dan kualitas produk yang dihasilkan oleh perusahaan.

\section{KESIMPULAN DAN SARAN}

\section{Kesimpulan}

Percentage pegawai engaged (memiliki keterlekatan pegawai yang tinggi) pada Generasi X lebih kecil dibanding percentage pegawai engaged pada Generasi $\mathrm{Y}$; percentage pegawai not-engaged (memiliki keterlekatan pegawai yang sedang) pada Generasi $\mathrm{X}$ lebih kecil dibanding percentage pegawai notengaged pada Generasi Y; serta percentage pegawai actively disengaged (memiliki keterlekatan pegawai yang rendah) pada Generasi X lebih besar dibanding percentage pegawai actively disengaged pada Generasi $\mathrm{Y}$.

Pada pegawai PT. Yudhistira Ghalia Indonesia Generasi $\mathrm{X}$ dan Generasi Y, quality of work life berpengaruh positif secara signifikan terhadap kepuasan kerja (job satisfaction); quality of work life berpengaruh positif secara signifikan terhadap employee engagement; serta job satisfaction berpengaruh positif secara signifikan terhadap employee engagement.

Perbedaan pengaruh quality of work life terhadap employee engagement antara Generasi $\mathrm{X}$ dan Generasi Y adalah tidak signifikan (not significant); serta perbedaan pengaruh job satisfaction terhadap employee engagement antara Generasi X dan Generasi $\mathrm{Y}$ adalah tidak signifikan (not significant) sehingga 
dapat dinyatakan bahwa generasi tidak berperan sebagai moderator (variabel moderasi) yang bermakna kuat-lemahnya pengaruh antara variabel laten tidak tergantung pada generasi.

\section{Saran}

Lima indikator dengan factor loading terbesar (terkuat) yang dapat digunakan sebagai aksi oleh PT. Yudhistira Ghalia Indonesia untuk memperoleh reaksi dari pegawai berupa peningkatan keterlekatan pegawai adalah Pada pegawai Generasi X, aksi yang dapat dilakukan oleh PT. Yudhistira Ghalia Indonesia untuk memperoleh peningkatan employee engagement adalah peningkatan terhadap kesempatan yang sama untuk memperoleh promosi yang dibarengi dengan kenaikan gaji; peningkatan terhadap tunjangan kesehatan yang diberikan perusahaan kepada pegawai; peningkatan terhadap kerjasama antara rekan kerja; perusahaan mengatasi perselisihan (konflik) berdasarkan peraturan dan hukum yang berlaku; serta peningkatan terhadap pelayanan dan kualitas produk yang dihasilkan oleh perusahaan.

Pada pegawai Generasi Y, aksi yang dapat dilakukan oleh PT. Yudhistira Ghalia Indonesia untuk memperoleh peningkatan employee engagement adalah peningkatan terhadap gaji berdasarkan pekerjaan yang menjadi tanggung jawab pegawai dan prestasi kerja pegawai; peningkatan terhadap kesempatan promosi berdasarkan prestasi kerja pegawai; peningkatan terhadap dukungan dari atasan pegawai; peningkatan terhadap otonomi (kesempatan untuk mengambil keputusan) saat melakukan pekerjaan; serta peningkatan terhadap kesempatan untuk mengungkapkan pendapat.

Pada pegawai Generasi X dan Generasi Y, aksi yang dapat dilakukan oleh PT. Yudhistira Ghalia Indonesia untuk memperoleh peningkatan employee engagement adalah peningkatan terhadap bonus yang diberikan sesuai dengan kinerja pegawai; peningkatan terhadap penerimaan perusahaan atas ide-ide dan inisiatif pegawai; peningkatan terhadap penghormatan personal privacy pegawai; serta peningkatan terhadap penggunaan kemampuan, keterampilan, dan pengetahuan yang pegawai miliki dalam menyelesaikan tanggung jawab (work responsibility) pegawai.

Hasil analisis SEM-PLS dengan selang kepercayaan 95\% diperoleh nilai $\mathrm{R}$-square menunjukkan bahwa quality of work life dan kepuasan kerja (job satisfaction) secara moderat mampu menjelaskan keragaman keterlekatan pegawai (employee engagement), sehingga untuk analisis selanjutnya, perlu memperkaya variabel laten yang diasumsikan secara kuat mampu menjelaskan keragaman keterlekatan pegawai (employee engagement).

\section{DAFTAR PUSTAKA}

Agung IGN. 2006. Statistika: Penerapan Model RerataSel Multivariat dan Model Ekonometri dengan SPSS. Jakarta: Yayasan SAD Satria Bhakti.

Deshwal S. 2015. A study of job satisfaction in relation to employee engagement. International Journal of Applied Research 1(9): 303-304.

Fatehi B, Amini I, Karimi A, Azizi B. 2015. Impact of quality of work life on job satisfaction (case study: sport Teachers in Department of Education from Urmia). Research Journal of Sport Sciences 3(1): 15-22.

Flippo EB. 1997. Manajemen Personalia Jilid 2; Masud M, Alih bahasa. Jakarta: Erlangga.

Gall MD, Borg WR, Gall JP. 2007. Education Research: An Introduction. 7th Edition. Gall Publisher: Allyn \& Bacon.

Gallup. 2013. There's a Generation Gap in Your Workplace. Gallup, Inc. Waktu unduh https:// news.gallup.com/businessjournal/163466/ generation-gap-workplace.aspx [2018 Juli 25].

Ghozali I, Latan H. 2015. Partial Least Square: Konsep, Teknik, dan Aplikasi menggunakan Program SmartPLS 3.0. Semarang: Badan Penerbit Universitas Diponegoro.

Hewitt A. 2015. Aon Hewitt's Model of Employee engagement. AON Inc. Waktu unduh https:// www.aonhewitt.co.nz/getattachment/770460289992-4d77-868a.../file.aspx [2016 Agustus 02].

Janah N, Sukmawati A, Afendi FM. 2017. Pengaruh spritualitas kerja terhadap keterlekatan karyawan melalui kepuasan kerja pada UKM kota Bogor. Jurnal Manajemen dan Organisasi VIII (2):134 142. https://doi.org/10.29244/jmo.v8i2.19990.

Khan IU, Ahmed K, Zulqarnain W, Jamil S. 2015. Impact of HR competencies on employees' job satisfaction. Journal of Resources Development and Management 5: 15-27.

Kupperschmidt BR. 2000. Multigenerational employees: strategies for effective management. The Health Care Manager Journal 19(1):65-76. https://doi.org/10.1097/00126450-200019010- 
00011.

Kwasira J, Waigwa MN. 2014. An assessment of the relationship between job satisfaction and employee engagement among teachers in Nakuru North Sub-County. Internaational Journal of Science and Research 3(10): 1335-1339.

Laterna. 2015. Cultivating Employee engagement: Enlightening Leaders' Perspective. Jakarta: Prasetiya Mulya Executive Learning Institute.

Lockwood NR. 2007. Leveraging Employee engagement for Competitive Advantage: HR's Strategic Role. https://pdfs.semanticscholar.org/ acc4/4ab3d4cb3c648cb2993fe705129984440ff e.pdf. [2018 Agustus 17].

Luthans F. 2005. Organizational Behavior 10 th ed. New York: Mc Graw-Hill/Irwin.

MetLife Mature Market Institute \& Generations United. 2009. Generation in the Workplace: A Workbook Engaging the Best Talent of All Ages. New York (US): Metropolitan Life Insurance Company.

Park J, Gursoy D. 2012. Generation Effects on Work Engagement Among U.S. Hotel Employees. InternationalJournalofHospitalityManagement. 31(4):1195-1202.https://doi.org/10.1016/j. ijhm.2012.02.007.
Rizaliani A. 2016. Analisis pengaruh kualitas kehidupan kerja (quality of work life) terhadap keterlekatan pegawai (employee engagement) [tesis]. Jakarta: Program Pascasarjana Universitas Indonesia.

Rusdin. 2015. Faktor kualitas kehidupan kerja dan keterlekatan pegawai: survey terhadap manajer madya pada badan usaha milik negara di Indonesia.Business Management Journal 11(2):83-119.https://doi.org/10.30813/bmj. v11i2.627.

Saks AM. 2006. Antecedents and consequences of employee engagement. Journal of Managerial Psychology 21(7):600-619. https://doi. org/10.1108/02683940610690169.

Sorenson S. 2013. How Employee engagement Drives Growth. https://www.gallup.com/ workplace/236927/employee-engagementdrives-growth.aspx. [2018 Agustus 17].

Tabassum A. 2012. Interrelations between quality of work life dimensions and faculty member job satisfaction in the private Universities of Bangladesh. European Journal of Business and Management 4(2): 78-89. 